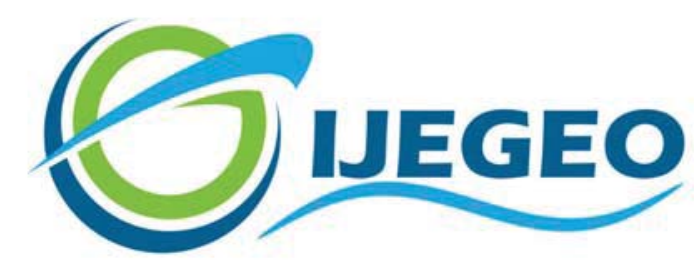

International Journal of Environment and Geoinformatics (IJEGEO) is an international, multidisciplinary, peer reviewed, open access journal.

\title{
Environmental Justice and Nuclear Accidents: The Case of Chernobyl Disaster
}

\section{Emrah AKYÜZ}

\section{Chief in Editor}

Prof. Dr. Cem Gazioğlu

\section{Co-Editors}

Prof. Dr. Dursun Zafer Şeker, Prof. Dr. Şinasi Kaya,

Prof. Dr. Ayşegül Tanık and Assist. Prof. Dr. Volkan Demir

Editorial Committee (September 2021)

Assoc. Prof. Dr. Abdullah Aksu (TR), Assit. Prof. Dr. Uğur Algancı (TR), Prof. Dr. Bedri Alpar (TR), Assoc. Prof. Dr. Aslı Aslan (US), Prof. Dr. Levent Bat (TR), Prof. Dr. Paul Bates (UK), İrşad Bayırhan (TR), Prof. Dr. Bülent Bayram (TR), Prof. Dr. Luis M. Botana (ES), Prof. Dr. Nuray Çağlar (TR), Prof. Dr. Sukanta Dash (IN), Dr. Soofia T. Elias (UK), Prof. Dr. A. Evren Erginal (TR), Assoc. Prof. Dr. Cüneyt Erenoğlu (TR), Dr. Dieter Fritsch (DE), Prof. Dr. Çiğdem Göksel (TR), Prof.Dr. Lena Halounova (CZ), Prof. Dr. Manik Kalubarme (IN), Dr. Hakan Kaya (TR), Assist. Prof. Dr. Serkan Kükrer (TR), Assoc. Prof. Dr. Maged Marghany (MY), Prof. Dr. Michael Meadows (ZA), Prof. Dr. Nebiye Musaoğlu (TR), Prof. Dr. Masafumi Nakagawa (JP), Prof. Dr. Hasan Özdemir (TR), Prof. Dr. Chryssy Potsiou (GR), Prof. Dr. Erol Sarı (TR), Prof. Dr. Maria Paradiso (IT), Prof. Dr. Petros Patias (GR), Prof. Dr. Elif Sertel (TR), Prof. Dr. Nüket Sivri (TR), Prof. Dr. Füsun Balık Şanlı (TR), Prof. Dr. Uğur Şanlı (TR), Duygu Ülker (TR), Prof. Dr. Seyfettin Taş (TR), Assoc. Prof. Dr. Ömer Suat Taşkın (TR), Assist. Prof. Dr. Tuba Ünsal (TR), Dr. Manousos Valyrakis (UK), Dr. İnese Varna (LV), Dr. Petra Visser (NL), Prof. Dr. Selma Ünlü (TR), Assoc. Prof. Dr. Oral Yağcı (TR), Prof. Dr. Murat Yakar (TR), Assoc. Prof. Dr. İ. Noyan Yılmaz (AU); Assit. Prof. Dr. Sibel Zeki (TR) 
Review Article

\title{
Environmental Justice and Nuclear Accidents: The Case of Chernobyl Disaster
}

\author{
Emrah Akyüz iD \\ Department of Management and Organization, Bingöl Vocational School of Social Sciences, University of Bingöl, City, Bingöl/TR
}

Received 26.01.2021

E-mail: emrahylsy@hotmail.com Accepted 05.04.2021

How to cite: Akyüz (2021). Environmental Justice and Nuclear Accidents: The Case of Chernobyl Disaster, International Journal of Environment and Geoinformatics (IJEGEO), 8(3):369-375. doi. 10.30897/ijegeo.868987

\begin{abstract}
Nuclear energy is one of the most important components of the world electricity supply in today's world. It provides approximately $21 \%$ of electricity in OECD countries. However, there has been a growing social and academic debate over the use of nuclear energy because the fact that there have been serious incidents and accidents at nuclear power stations indicates that the security risk associated with NPPs is not low. Particularly major nuclear accidents, Fukushima and Chernobyl, can cause the release of radiation into the environment. However, environmental contamination is not shared equally among people who trigger environmental injustice issues. There has been no comprehensive research that investigates nuclear accidents from the perspective of environmental justice theory so far. The main purpose of this study is to argue whether or not nuclear accidents cause environmental injustice. The results show that the major nuclear accident, the Chernobyl, has caused distributive and intergenerational environmental injustice.
\end{abstract}

Keywords: Environmental Justice, Nuclear Energy, Nuclear Accidents, Chernobyl.

\section{Introduction}

Nuclear energy is one of the most important energy sources which provide about $10 \%$ of the world's electricity. However, nuclear energy is a controversial topic due to its risks to the environment and public health. The most important risk associated with nuclear energy is nuclear accidents. Nuclear energy technology has advanced safety systems, but the accident risk associated with nuclear power plants cannot be prevented because there is no zero risk on the earth; meaning that everything is risky. Indeed, major nuclear accidents, the Chernobyl and Fukushima, indicate that nuclear energy is vulnerable to accidents raised by natural events and human mistakes or terrorist attacks.

The worst nuclear accident that the world has witnessed is the Chernobyl disaster which happened in 26 April 1986 in Ukraine. The accident which released radioactive elements into the atmosphere has caused environmental disaster in the region. In other words, all elements of the environment including air and soil have been contaminated by the Chernobyl Nuclear Accident. There is growing evidence of the Chernobyl disaster's direct effect on the population. Radioactive contamination in Chernobyl has still posed risks to the environment and public health (De Boer and Catsburg, 1988). Related researches illustrate that the lifetime risks for leukaemia and thyroid cancer have been increased in Chernobyl. However, environmental contamination is not shared equally among people which raises environmental injustice problem in Chernobyl. The unequal distribution of environmental burdens throughout society is still on debate. Accordingly, there is a need for a discussion on whether or not major nuclear accidents (particularly the Chernobyl nuclear event) cause environmental injustice.

The main purpose of this study is to argue whether or not major nuclear accidents (particularly the Chernobyl nuclear event) cause environmental injustice through critically analysis of the related literature on the Chernobyl disaster. This paper consists of two main parts. It firstly discussed the meaning of environmental justice and the types of environmental justice including distributive justice, ecological justice, procedural justice, and intergenerational justice. It then argues how the impact of the Chernobyl nuclear accident on the environment and public health can be approached from the perspective of environmental justice theory.

\section{The Term "Environmental Justice”}

The term environmental justice is understood in different ways depending on the context and perspective (Pedersen, 2010; Millner, 2011). Historically speaking, environmental justice can be defined as the struggle against perceived social inequalities related to environmental concerns in the US (Walker and Bulkeley, 2013). Environmental justice can be seen as a powerful lens through which to make sense of struggles over environmental issues and natural resources. Environmental justice is a proportionate share issue regarding environmental burdens and risks (Kaswan, 1997; Millner, 2011). This definition stays insufficient to draw the boundary of environmental justice because it is also the distribution of environmental goods such as green area (Strelau and Köckler, 2008). Differently, Nigel Clark et al. (2013) emphasize representation aspect of environmental justice that it is a way to address 
unfairness and inequity raised from environmental harms. These all definitions, however, stay vague in a sense as they do not define instruments that victims of environmental crimes can apply to address the justice issue.

More broadly, environmental justice can be defined as a specific social groups' struggle over perceived environmental harms and benefits. It is mainly considered as a response to perceived risks for already "marginalised" and "disadvantaged" social groups (Walker and Bulkeley, 2013; Millner, 2011; Yang, 2011). Accordingly, environmental justice appears efforts to identify and address disproportionate environmental harms experienced by "low-income populations" (Schlosberg, 2009). This may be because of the fact that most environmentally harmful operations are seen in poorer, more socially disadvantaged areas of countries (Hofrichter, 1993). This identification may be true for some specific cases. For example; 164,000 people had to be evacuated from their homes after the accident in Fukushima (Do, 2019). Only 35,000 of them live in temporary housings paid by the government as they do not afford a new house (Mann et al., 2018). The radiation level in temporary housings is higher than the normal level and they have very poor living conditions (Akyüz, 2021). In contrast, those who have enough economic budgets live out of the contaminated area such as in Tokyo which is relatively much less contaminated. This demonstrates that poorer communities face distributive injustice issue more than richer ones in nuclear accidents. Limiting environmental justice to only poor people or using only economic criteria, however, seems a narrow definition because nuclear accidents pose risk to all communities regardless of their wealth as it releases radioactive materials into air and water resources (such as ground water) that are shared by all people for survival. Even rich people need to breath the air or to drink water which has been contaminated, for example, by Fukushima nuclear accident in Japan or Chernobyl accident in Ukraine. Environmental justice is, therefore, the principle that all human beings are entitled to equal protection of environmental regulations.

On the other hand, some scholars develop human rights approach to define environmental justice. Karen Bell (2011), for example, categorises environmental justice as basic human rights to healthy environment (Akyüz, 2021). From this perspective, environmental justice emerges as a result of the enjoyment of the distinct right to safe environment. Slightly differently, Pedersen (2010) point out that environmental justice is the struggle over both access and representation in decisionmaking; which refers to the enjoyment of procedural environmental rights that are recognised by different international documents as key element of modern environmental law. The 1992 Rio Declaration and the Aarhus Convention, for example, inspire countries to guarantee the right to access to information: to participation in decision making process; and to access to justice in order to achieve safe environment (UN, 1992; EUROPA, 1998). It may, however, be, narrow or problematic to limit environmental justice to only procedural rights because they (particularly public participation in decision-making) may not exist in some countries with non-democratic or totalitarian regimes such as North Korea or Syria. Accordingly, at international level, environmental justice may be better achieved through more universal standards that can be applied in all countries such as substantive human rights that are entitled to all people regardless of their age, gender or country. The right to freedom of expression, for example, enables even concerned groups to raise their objections to environmental decisions (Akyüz, 2020). For instance; Austria's government began construction of the Zwentendorf Nuclear Power Plant in 1972. The anti-nuclear movement by concerned citizens, which is the exercise of the right to expression, to association and protest, forced the Government to hold a referendum which resulted in 50.5\% against nuclear power (Pilat, 1982). In this sense, environmental justice is also the environmental movement, which requires the right to expression and to protest, to control environmental harms and benefits. More broadly, environmental justice, therefore, is the recognition of affected community by the environmental issues; representation of concerned groups in environmental decision-making process; fair distribution of environmental harms; and redress and compensation for those parties who suffer the effects of ecological problems.

\section{Types of Environmental Justice}

There are mainly four types of environmental justice including distributive justice, ecological justice, procedural justice and intergenerational justice. The most common one is distributive justice. Environmental goods and harms are not equally distributed in the world (Strelau and Köckler, 2016). This results in distributive (in) justice which is the idea of balancing benefits (e.g., clean air, green spaces) and costs (e.g., pollution) associated with the way in which we disseminate and consume environmental entitlements (Arcioni and Mitchell, 2005; Davodi-Far, 2009). "While all communities bear some or much of the burdens of industrial society, the critical question in distributive justice is, particularly, whether these burdens are distributed equally" (Kaswan, 2003). This may be a key issue in nuclear energy discussion because all citizens benefit from electricity generated by nuclear stations equally but people living near the station is always more vulnerable to a potential nuclear accident than those who are far away from it. For example; while 116,000 people who were evacuated from their homes within a $30 \mathrm{~km}$ radius of the Chernobyl nuclear stations are unable to return to their homes due to high radioactive contamination (Saenko et al., 2011), others who live 30 $\mathrm{km}$ away from the station still enjoy their properties. That is- there are certain groups in Chernobyl that are disproportionately exposed to radioactive contamination. The unequal distribution of environmental burdens throughout society, therefore, is a dominant issue in nuclear accidents. The second type is procedural environmental justice emphasising issues of participation in decision making process affecting their environments, 
access to information and access to justice for environmental harms (Pedersen, 2010; Millner, 2011; Arcioni and Mitchell, 2005). Procedural justice can be regarded fair outcomes that provide a useful vehicle to reduce dissatisfaction with unfavourable decisions (Lawrence et al., 1997). This is shared by many scholars that taking particularly the viewpoint and needs of interested parties into account makes the decisionmaking process more fair, impartial and neutral as it may reflect concerns, thoughts of more diverse groups (Beierle and Cayford, 2002). Procedural justice is, however, not important for only itself. It also contributes to distributive justice because benefits and environmental burdens may be distributed more fairly in a way that gives opportunities concerned citizens to influence decisions that affect their environment. However, it seems too optimistic to expect that procedural justice always reflects rational choices or bring justice and fairness. For instance, a decision taken the consensus of such a diverse group on usage of nuclear energy can be an effective solution to air pollution caused by too much consumption of fossil fuels (such as oil, coal and gas) as it does not release any gases. However, a future accident (maybe 20 or 30 years later) on this nuclear station may affect the environment of future generation negatively. That is- procedural and distributive justice for current citizens may be (in) justice for future generations. In other words, procedural justice for current generation may result in intergenerational (in) justice issue.

The third type is procedural environmental is intergenerational justice. The common view is that the enjoyment of the environment of future generation depends on what they will inherit from us: which means unborn baby may have a right to protection from eco harms that rises from current generation (Weston, 2012). Some scholars take opposite view that they cannot have a right because they do not exist and there are not representable (Beckerman and Pasek, 2001). Both arguments appear to be acceptable partly. Undoubtedly, they will benefit from the sacrifices and investments made by the current generation. That is- we have a moral obligation to preserve the environment for future generations (Weston, 2012). What the issue is, however, how our decision related to the environment may affect environmental quality of future generation (adversely or favourably) is not clear or unknown. If we take opposite position in the previous example, a nuclear accident may not ever happen; which means future generation can have safer environment due to less usage of fossil fuels as nuclear energy does not release any gases. From this perspective, it, therefore, does not seem practically feasible to achieve intergenerational justice.

Fourthly, ecological justice is increasingly being applied to the non-human sphere of the environment and animals (Baxter, 2005). Ecological justice expresses a spiritually grounded moral posture of respect and fairness toward all creation including people and non-human world (Stevis, 2000). Green thinkers argue that non-human world have rights that would put them on an equal footing morally with humans because nature is valuable in itself or for its own sake (Batavia and Nelson, 2017: 366). Undoubtedly, the decision related to the environment affects not only people but also living creatures. For example, one empirical study has provided that radioactive contamination in Fukushima has caused a reduction in size, slowed the growth, and resulted in high rates of mortality and morphological abnormality in one of the most common butterfly species in Japan, i.e. the pale grass blue butterfly (Taira et al., 2014). This paradigm, however, can be challenged by the idea that justice also has other important dimensions such as presentation (Kortetmäki, 2016). Presentation is essential to understand today' forms of (in) justice. The issue on ecological justice rises from that fact that the nature or non-human world cannot speak or express their thoughts. That is- they are not able to present themselves. The question of who will claim on behalf of them stays unclear. Animals are not regulated by the principles of justice because they are not capable of explaining a rational plan of life. Marcel Wissenburg (1998), however, takes an opposite view that justice can be applied to animals, but it is the individual moral of people to seek to promote it for them. However, it seems that he ignores the fact that if people speak on behalf of them-this seems the only option- what it is good for non-human world would be bad for people and vice versa. Marcel Wissenburg (2006) underlines the same point that "protecting the nature is not necessarily to the advantage of people, whereas giving humans what they deserve is not necessarily good for the ecology."

\section{Environmental Injustice in Chernobyl Nuclear Accident}

Nuclear events do not happen as often as other natural and man-made accidents do. However, the risks associated with nuclear power stations are not low. Unexpected events, terrorist attacks or wrong decisions taken during the management of a nuclear plant may cause a big nuclear explosion into the surrounding communities that directly threatens the environment (Adamantiades and Kessides, 2009). The risks associated with nuclear power, such as the radioactive waste produced by nuclear plants and the possibility of a catastrophic accident, are a serious threat not only to the environment but also to the public (Ho and Kristiansen, 2019). Nuclear events release dangerous materials into the air that people breathe and other water resources, such as the marine environment (i Batlle et al., 2018). Chernobyl is a specific case which shows how exposure to environmental risk related to nuclear accidents directly affects the environment and public health (Yablokov et al., 2010).

The most serious industrial accident in the 20th century happened in Chernobyl on 26 April 1986 when operators of the power plant ran a test on an electrical control system of one of the reactors (Saenko et al., 2011). The Chernobyl nuclear accident released radioactive materials into the atmosphere in the form of radioactive gases or radioactive particles (aerosols) (Steinhauser et al., 2014). The Chernobyl event in 1986 resulted in land in the Ukraine, Russia and Belarus being contaminated 
with radio nucleotides (Saenko et al., 2011). Before the Chernobyl accident, the area was covered with forest, bodies of water and urban centres as shown by Figure 1. After the Chernobyl disaster, drinking water supplies and agricultural produce have become an increasingly serious issue for the local people in the region due to the radioactive contamination (Drozd et al., 2015; Komissarova et al., 2019).

The contaminated environment in Chernobyl is a serious risk to not only the environment but also to the public (Yablokov et al., 2010) because the environment comprises the air people breathe, the water humans drink and the ground individuals walk on. A clean environment is the most important human basic need. The basic elements for human beings include air, water, soil, animals and plants. People can live without water for a day and without food for a couple of weeks, but they cannot live without the environment. Food, water and air are basic human needs that all people must meet for survival. Otherwise, people cannot exist without them. They are all provided from the nature; which means all human beings are physically dependent on the environment (Akyüz, 2020). As nature is the life-giving and nurturing aspects of everything that human beings need, the environment is the most vital human requirement for existence. If human survival is not possible without the environment, and if the environment provides all basic human needs, it can be automatically interpreted that the contaminated environment poses serious risks to the human health as evidenced in Chernobyl.

The discussion above indicates that the threat to the environment is a threat to human life. For this reason, the health of many people remains at risk due to environmental contamination in Chernobyl (Cardis and Hatch, 2011). The related literature on the Chernobyl accident shows that there is a potential increase in the risk of acquiring certain forms of cancer, particularly thyroid and solid cancers, for those living in the most contaminated areas around Chernobyl (Shibata et al., 2001; Drozd et al., 2015). Similarly, many people may have been exposed to excess radiation, mainly through contamination by iodine-131 and various caesium isotopes, and it is estimated that this may also have elevated the long-term risk of cancer in or around Chernobyl (Takamura and Yamashita, 2011). It is estimated that thousands of people have died between 1986 and 2000 due to cancer-orientated illnesses as a result of the Chernobyl accident according to the report by Chernobyl Form (World Health Organization, 2005; Petryna, 2013). This fact shows, or proves, that the risks to human health due to this accident may turn into elevated levels of premature death in the long term. On this basis, nuclear accidents do pose a risk not only to only health at present but also in a long-term sense.

The environmental risks of nuclear accidents are not limited to public health and human life. A few researchers have illustrated how nuclear accidents also pose risks to properties which are of significance to adequate standards of living (Schwartz, 2006). Land contamination forces large numbers of people to relocate, and thus to leave homes that may never be used again (Smith and Beresford, 2005). Empirical research and official statistics support the claim that 116,000 people in Chernobyl, had to be evacuated from their homes after the accident (Saenko et al., 2011: p. 239). The properties within a $30 \mathrm{~km}$ radius of the Chernobyl nuclear stations are at particularly high risk due to ongoing radioactive contamination; that is why, it is declared as "exclusion zone" (Steinhauser et al., 2014). For this reason, those who were evacuated in Chernobyl will never be able to return to their homes because the area within a $30-\mathrm{km}$ radius from the Chernobyl is declared too dangerous for human-beings: which means their properties including the land, houses, cars or other belongings have been affected by the accident seriously as shown by Figure 2. These entire mean that thousands of people have suffered incur damage to their property raised by the Chernobyl disaster. That is, the peaceful enjoyment of possessions may be impossible given the contamination to each environment. This shows that unsafe environment is a barrier to the enjoyment of the right to property for the evacuated people in Chernobyl.

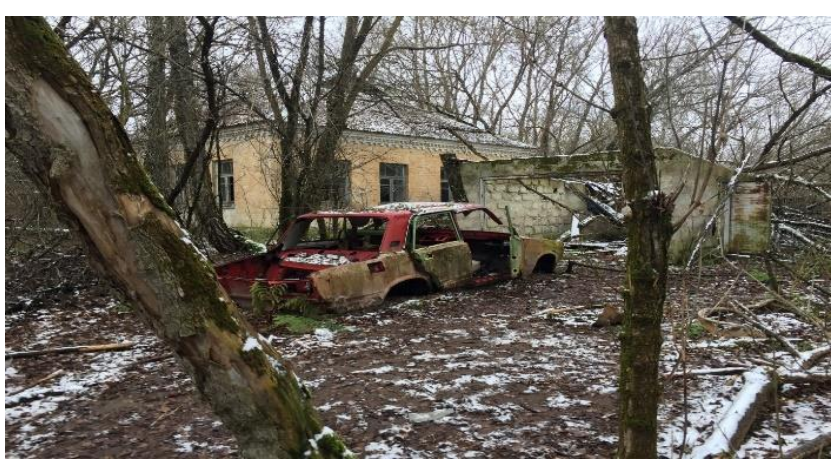

Figure 1: An Evacuated Property in Chernobyl, taken by the researcher (Dr. Emrah Akyüz)

As Chernobyl has affected thousands of or millions of people's living conditions and ecology negatively (Barnett, 2007), the issue in promotion of the environmental justice becomes a subject of academic debate in nuclear energy literature (Fan, 2006: Hoffman, 2001; Kyne and Bolin, 2016; Huang et al., 2013). Justice concerns about nuclear accidents include the large potentially exposed populations living under contaminated environment (Kyne and Bolin, 2016). The Chernobyl nuclear accident resulted in an unprecedented release of radioactive material, with adverse consequences for the environment. The literature agrees that accidents contaminate, in particular, the territory and natural resources (such as groundwater) near the station through the release of radioactive materials. Agricultural products may lead to unacceptable levels of radionuclides in food. However, unlike other man-made or natural accidents, they- depending on the level of the radioactive contamination- have long term serious impacts on the environment and human health (Christodouleas et al., 2011). It is estimated that their impacts on the environment will last hundreds of years (Blakemore, 2019): which means even unborn baby and non-human world may suffer from radioactive contamination. Future generation has a right to live in a safe environment. However, the Chernobyl disaster has 
been still affecting the environment and the public health since 1986 which means that the accidents pose risks to not only the current generation but also unborn baby. How the waste will be handled in future is not known which means that future generation will be at risks associated with the Chernobyl disaster. That isinternational (in) justice issue is one of main characteristics of nuclear accidents.

More urgent issue is that the current generation already live under contaminated environment (Petryna, 2013; Barnett, 2007). Millions of people living in contaminated areas are still exposed to a higher dose of radiation than the limit recommended (Saenko et al., 2011; Kinly III, 2006; Petryna, 2013; Barnett, 2007). However, environmental harm of the Chernobyl disaster has not shared equally although the costs of the station such as electricity or environmental benefit of NPPs might be shared fairly. For instance, while those who live near/in Chernobyl are under threat of cancer or other serious diseases, such as leukaemia and disorders of the bone, muscle and connective tissue (Kinly III, 2006), those who are far away from Chernobyl are not at serious risks. Another example is that while those who lived near the station lost their all properties, residents who live $30 \mathrm{~km}$ further away from the station still use the properties. Those facts cause distributive injustice because while electricity generated from the Chernobyl Power Plant was shared equally environmental hazards raised by the Chernobyl disaster is not equally distributed. This clearly shows that distributive injustice is another main issue in nuclear accidents matters. Distributive injustice appears a problem for some specific groups, mostly those who live near the NPPs and economically poorer communities.

Therefore, the immediate consequences and ongoing effects of Chernobyl accident illustrate that contaminated environments pose risks to human life, health and other properties. As Fukushima and other major nuclear accidents have contaminated all elements of the environment, this in turn affects the realisation/enjoyment of human rights, and as such nuclear accidents can be considered in the context of environment rights. As nuclear accidents release radioactive materials into all entitlements of the environment that people are dependent on, contaminated environment which has been distributed unequally raises the issue in environmental justice for especially those who live close the damaged stations.

\section{Conclusion}

This research has discussed whether or not the Chernobyl nuclear accident has caused environmental injustice issues in any way. The world has witnessed many nuclear accidents and incidents so far. Chernobyl is regarded the most dangerous one because it has released radiation into the atmosphere which has still affected public health and resulted in some serious illnesses, particularly cancer-related health problems in the region. It is known that since 1952, the rate of civilian nuclear accidents has decreased significantly over time from the 1970s. In this regard, it has long been fixed at approximately 0.003 events per year per facility. Although it is a reality that the measures taken make nuclear energy safer, the increasing number of facilities may negatively change the number of accidents per facility in question for a certain period of time. The related literature on Chernobyl nuclear accident indicates that nuclear events pose risks to the environment that provide for the basic needs of human beings, including air, water and food. The contaminated environment has resulted in public health problems in the region because when people come into contact with a radioactive environment through such elements as contaminated food, water, air, or via the skin, empirical research indicates that a number of serious illnesses, most notably cancer, emerge as serious potential risks to human health.

The result of this research shows that the environmental impact of the Chernobyl disaster has caused environmental justice issues including intergenerational injustice and distributive injustice in/around Chernobyl since the accident happened in 1986. The discussion above shows that the Chernobyl nuclear accident has affected the environment and public health since the accident happened in 1986; meaning that the accident has long-term impact on people which can be defined as international injustice. People have a right to live in a safe environment. However, the Chernobyl disaster has polluted the environment of people who were born after the accident. More importantly, the impact of the Chernobyl disaster will last for hundred years meaning that future generations will be affected by the radioactive contamination. All these show that the Chernobyl disaster has caused intergenerational injustice issues.

Another environmental injustice issue raised by the Chernobyl disaster is distributive injustice. The discussion above indicates that Chernobyl residents faced environmental injustice issues from the disproportionate risk burdens they bear. While those who lived near the Chernobyl nuclear station lost their all properties and are at risk of health problems including cancer residents who live $30 \mathrm{~km}$ further away from the station still use the properties and are not under serious threat. All these mean that the environmental harm of the Chernobyl disaster has not shared equally. Therefore, distributive injustice seems an issue for unequal distribution of environmental harms in Chernobyl.

\section{References}

Adamantiades, A., Kessides, I. (2009). Nuclear Power for Sustainable Development: Current Status and Future Prospects. Energy Policy, 37(12), 5149-5166.

Akyüz, E. (2020). Çevre ve İnsan Hakları: Türkiye Üzerine Bir Araştırma. Çanakkale: Paradigma Akademi Yayınlart.

Akyüz, E. (2021). Nuclear Power and Human Rights in Japan: The Fallout of Fukushima. London: Lexington Books.

Akyüz, E. (2021). The Development of Environmental Human Rights. International Journal of Environment 
and Geoinformatics, 8(2), 218-225. doi.10. 30897/ijegeo.839725.

Arcioni, E., Mitchell, G. (2005). Environmental Justice in Australia: When the RATS Became IRATE. Environmental Politics, 14(3), 363-379.

Barnett, L. (2007). Psychosocial Effects of the Chernobyl Nuclear Disaster. Medicine, Conflict and Survival, 23(1), 46-57.

Batavia, C., Nelson, M. P. (2017). For Goodness Sake! What is Intrinsic Value and Why Should We Care? Biological Conservation, 209, 366-376.

Baxter, B. (2005). A Theory of Ecological Justice. Oxon: Routledge.

Beckerman, Wilfred and Pasek, Joanna (2001). Justice, Posterity and the Environment. Oxford: Oxford University Press.

Beierle, T. C., Cayford, J. (2002). Democracy in Practice: Public Participation in Environmental Decisions. Washington: Resources for the Future.

Bell, K. (2011). Environmental Justice in Cuba. Critical Social Policy, 31(2), 241-265.

Blakemore, Erin (2019). The Chernobyl disaster: What happened, and the long-term impacts.

Cardis, E., Hatch, M. (2011). The Chernobyl AccidentAn Epidemiological Perspective. Clinical Oncology, 23(4), 251-260.

Christodouleas, J. P., Forrest, R. D., Ainsley, C. G., Tochner, Z., Hahn, S. M., Glatstein, E. (2011). Shortterm and Long-term Health Risks of Nuclear-PowerPlant Accidents. New England Journal of Medicine, 364(24), 2334-2341.

Clark, N., Chhotray, V., Few, R. (2013). Global Justice and Disasters. The Geographical Journal, 179(2), 105-113.

Davodi-Far, M. (2009). Environmental Sustainability and Distributive Justice: Are the Two Compatible? WIT Transactions on Ecology and the Environment, 1, 120-231.

De Boer, C., Catsburg, I. (1988). A Report: The Impact of Nuclear Accidents on Attitudes Toward Nuclear Energy. The Public Opinion Quarterly, 52(2), 254-261.

Do, X. B. (2019). Fukushima Nuclear Disaster displacement: How far people moved and determinants of evacuation destinations. International Journal of Disaster Risk Reduction, 33, 235-252.

Drozd, V. M., Saenko, V. A., Brenner, A. V., Drozdovitch, V., Pashkevich, V. I., Kudelsky, A. V., ... Reiners, C. (2015). Major Factors Affecting Incidence of Childhood Thyroid Cancer in Belarus After the Chernobyl Accident: Do Nitrates in Drinking Water Play a Role? PLoS One, 10(9), e0137226.

EUROPA (1998). Convention on Access To Information, Public Participation In Decision-Making And Access To Justice In Environmental Matters.

Fan, M. F. (2006). Environmental Justice and Nuclear Waste Conflicts in Taiwan. Environmental Politics, 15(03), 417-434.

Ho, S. S., Kristiansen, S. (2019). Environmental Debates over Nuclear Energy: Media, Communication, and the Public. Environmental Communication, 13(4), 431-439.
Hoffman, S. M. (2001). Negotiating Eternity: Energy Policy, Environmental Justice, and the Politics of Nuclear Waste. Bulletin of Science, Technology \& Society, 21(6), 456-472.

Hofrichter, R. (ed.) (1993). Toxic Struggles: The Theory and Practice of Environmental Justice. Philadelphia: New Society.

Huang, G. C. L., Gray, T., Bell, D. (2013). Environmental Justice of Nuclear Waste Policy in Taiwan: Taipower, Government, and Local Community. Environment, Development and Sustainability, 15(6), 1555-1571.

i Batlle, J. V., Aoyama, M., Bradshaw, C., Brown, J., Buesseler, K. O., Casacuberta, N., ... Nishikawa, J. (2018). Marine Radioecology after the Fukushima Dai-Ichi Nuclear Accident: Are We Better Positioned to Understand the Impact of Radionuclides in Marine Ecosystems? Science of the Total Environment, 618, 80-92.

Kaswan, A. (1997). Environmental Justice: Bridging the Gap Between Environmental Laws and Justice. American University Law Review, 47(2), 221-301.

Kaswan, A. (2003). Distributive justice and the environment. North Carolina Law Review, 81(3), 1031-1148.

Kinly III, D. (2006). Chernobyl's legacy: Health, environmental and socio-economic impacts and recommendations to the Governments of Belarus, the Russian Federation and Ukraine.

Komissarova, O., Paramonova, T. (2019). Land Use in Agricultural Landscapes with Chernozems Contaminated After Chernobyl Accident: Can We be Confident in Radioecological Safety Of Plant Foodstuff? International Soil and Water Conservation Research, 7(2), 158-166.

Kortetmäki, T. (2016). Is Broad the New Deep in Environmental Ethics?: A Comparison of Broad Ecological Justice and Deep Ecology. Ethics \& the Environment, 21(1), 89-108.

Kyne, D., Bolin, B. (2016). Emerging Environmental Justice Issues in Nuclear Power and Radioactive Contamination. International Journal of Environmental Research and Public Health, 13(7), 700.

Lawrence, R. L., Daniels, S. E., Stankey, G. H. (1997). Procedural Justice and Public Involvement in Natural Resource Decision Making. Society \& Natural Resources, 10:6, 577-589

Mann, C. L., Gillezeau, C. N., Massazza, A., Lyons, D. J., Tanaka, K., Yonekura, K., ... Katz, C. L. (2018). Fukushima triple disaster and the road to recovery: A qualitative exploration of resilience in internally displaced residents. Psychiatric Quarterly, 89(2), 383-397.

Millner, F. (2011). Access to environmental justice. Deakin Law Review, 16(1), 189-207.

Pedersen, O. W. (2010). Environmental Principles and Environmental Justice. Environmental Law Review, 12(1), 26-49.

Petryna, A. (2013). Life Exposed: Biological Citizens After Chernobyl. New Jersey, Princeton University Press. 
Pilat, J. F. (1982). Democracy or discontent? Ecologists in the European Electoral Arena. Government and Opposition, 17(2), 222-233.

Saenko, V., Ivanov, V., Tsyb, A., Bogdanova, T., Tronko, M., Demidchik, Y., Yamashita, S. (2011). The Chernobyl Accident and Its Consequences. Clinical Oncology, 23(4), 234-243.

Schlosberg, D. (2009). Defining Environmental Justice: Theories, Movements, and Nature. Oxford: Oxford University Press.

Schwartz, J. A. (2006). International nuclear third-party liability law: The response to Chernobyl. International nuclear law in the Post-Chernobyl period.

Shibata, Y., Yamashita, S., Masyakin, V. B., Panasyuk, G. D., Nagataki, S. (2001). 15 Years After Chernobyl: New Evidence of Thyroid Cancer. The Lancet, 358(9297), 1965-1966.

Smith, J. T., Beresford, N. A. (2005). Chernobyl: Catastrophe and Consequences. New York: Springer.

Steinhauser, G., Brandl, A., Johnson, T. E. (2014). Comparison of the Chernobyl and Fukushima Nuclear Accidents: A Review of the Environmental Impacts. Science of the Total Environment, 470, 800817.

Stevis, D. (2000). Whose Ecological Justice? Strategies: Journal of Theory, Culture \& Politics, 13(1), 63-76.

Strelau, L., Köckler, H. (2016). "It's Optional, not Mandatory": Environmental Justice in Local Environmental Agencies in Germany. Local Environment, 21(10), 1215-1229.

Taira, W., Nohara, C., Hiyama, A., Otaki, J. M. (2014). Fukushima's Biological Impacts: The Case of the Pale Grass Blue Butterfly. Journal of Heredity, 105(5), 710-722.

Takamura, N., Yamashita, S. (2012). Lessons from Chernobyl. Fukushima Journal of Medical Science, 57(2), 81-85.

UN (1992, August 12). Report of the United Nations Conference on Environment and Development.

Walker, G. P., Bulkeley, H. (2006). Geographies of Environmental Justice. Geoforum, 37(5), 655-659.

Weston, B. H. (2012). The Theoretical Foundations of Intergenerational Ecological Justice: An Overview. Human Rights Quarterly, 34(1), 251-266.

Wissenburg, M. (2006). Global and Ecological Justice: Prioritising Conflicting Demands. Environmental Values, 15(4), 425-439.

Wissenburg, Marcel. 1998. Green Liberalism: The Free and the Green Society. London: Routledge

World Health Organization (2005). Chernobyl: the true scale of the accident.

Yablokov, A. V., Nesterenko, V. B., Nesterenko, A. V., Sherman-Nevinger, J. D. (Eds.). (2010). Chernobyl: Consequences of the Catastrophe for People and the Environment. Boston: John Wiley \& Sons.

Yang, T. (2001). Environmental Regulation, Tort Law and Environmental Justice: What Could Have Been. Washburn Law Journal, 41, 607-628. 